\title{
Relationship between Soil and Plant Water Status in Wine Grapes under Various Water Deficit Regimes
}

\author{
Ana Centeno ${ }^{1}$, Pilar Baeza, and José Ramón Lissarrague
}

AdDITIONAL INDEX WORDs. Vitis vinifera, irrigation management, semiarid conditions, leaf water potential, stomatal conductance

SUMMARY. Limited water supply in arid and semiarid Mediterranean environments demands improving irrigation efficiency. The purpose of this study was to determine a functional relationship between soil water availability and wine grape (Vitis vinifera) water status to determine a threshold value of soil matric potential to trigger irrigation. Seasonal trends of soil water potential, leaf water potential, and stomatal conductance $\left(g_{s}\right)$ of 'Tempranillo' wine grape were determined in two deficit irrigation treatments replenishing $45 \%$ and $30 \%$ of the reference evapotranspiration, and in a third non-irrigated treatment during 2001 and 2002. Soil water potential was measured with granular matrix soil moisture sensors placed at $0.3 \mathrm{~m}\left(\Psi_{0.3}\right), 0.6 \mathrm{~m}\left(\Psi_{0.6}\right)$, and $1.2 \mathrm{~m}\left(\Psi_{1.2}\right)$ depths. The sensors at $0.3 \mathrm{~m}$ depth quickly responded to irrigation by increasing $\Psi_{0.3}$ levels. At the $0.6 \mathrm{~m}$ depth, $\Psi_{0.6}$ progressively decreased, showing significant differences between $\mathrm{Tl}$ and the rest of the treatments, while no significant differences in $\Psi_{1.2}$ were found. All relationships between profile soil matric potential and leaf water potential and $g_{s}$ were highly correlated. After integrating our data with previous studies, we suggest a whole profile soil water potential value of $-0.12 \mathrm{MPa}$ as threshold to trigger irrigation and avoid severe water stress during berry growth.

$\mathrm{M}$ ost cultivated vineyards in arid and semiarid environments grown under in the Mediterranean zone weather conditions, with irregular annual rainfalls ranging from 300 to $600 \mathrm{~mm}$ per year mainly during the dormant season, and high vapor pressure deficit and evaporation rates during a long summer, need to be irrigated during part of their seasonal cycle. The limited water resources characteristic of this region have promoted the development of several strategies of deficit irrigation. In a deficit irrigation system, only a fraction of the estimated crop evapotranspiration (ET) is replenished. Stored soil water is assumed to provide the remaining fraction. Usually, spring rainfalls and soil water content satisfied wine grape needs until berry set (mid June). In practical terms, vines grow throughout the season under controlled water deficit to prevent severe water stress.

Soil water deficit reduces vegetative growth (Deloire et al., 2004;

Departamento de Producción Vegetal: Fitotecnia, Universidad Politécnica de Madrid, Av. Complutense s/n. 28040 Madrid, Spain

We thank Dr. María Gómez del Campo and Jon Lizaso for their valuable suggestions on the manuscript.

${ }^{1}$ Corresponding author. E-mail: ana.centeno@upm.es.
Intrigliolo and Castel, 2006; Matthews et al., 1987; Paranychianakis et al., 2004), stomatal conductance (gs) (Cuevas et al., 2006; Dry and Loveys, 1999; Grimes and Williams, 1990), photosynthesis (Iacono and Sommer, 1996), and reproductive growth and yield (Dry et al., 2001; Escalona et al., 2003; Tregoat et al., 2002). Thus, soil water availability and vine water status need to be evaluated simultaneously to guarantee adequate vine irrigation management; that is, to prevent vine water stress.

Different methods are used to determine soil water availability. Some of them estimate volumetric soil water content [time-domain reflectometer (TDR) and neutron probe], while others measure matric water potential/soil moisture tension (tensiometer, gypsum blocks, and granular matrix soil moisture sensor). It is difficult to measure an effective soil water potential within the rhizosphere because soil water potential varies diurnally along with the root and plant potential (Nadler and Heuer, 1997). However, the information of soil water content is a good tool to evaluate the plant water status (Girona et al., 2006; Medrano et al., 2003; Van Leeuwen et al., 2001; Williams and Trout, 2005). Critical to the use of soil moisture sensors is the threshold or lower limit value, which indicates the level to which soil can dry before irrigation is required. Generally, threshold values are selected to ensure that crops do not experience water stress or a loss in production. A large number of sensors must be installed to correctly monitor soil water content and to detect the spatial distribution of water in the root zone. Furthermore, because drip irrigation does not regularly wet the soil, special care must be taken for sensors to evaluate the wetted soil volume (Davenport et al., 2008; Stevens and Douglas, 1994; Stevens and Harvey, 1996). In addition, uneven distribution of roots within the soil poses another difficulty. Measurements in zones with large root density may be closely associated with plant water status under non-limited water availability (Nadler and Heuer, 1997; Schultz, 2003). However, under limited water supply or rain-fed conditions, vines can take up water from deeper zones with less root density but higher moisture. Therefore, an integrated soil moisture profile may provide a better assessment of soil water supply than single-depth soil moisture readings.

Watermark $₫$ sensors (Irrometer, Riverside, CA) are granular matrix sensors (GMS) for electronically

\begin{tabular}{lllc}
\hline $\begin{array}{l}\text { Units } \\
\begin{array}{l}\text { To convert U.S. to SI, } \\
\text { multiply by }\end{array}\end{array}$ & U.S. unit & SI unit & $\begin{array}{l}\text { To convert SI to U.S., } \\
\text { multiply by }\end{array}$ \\
\hline 0.1 & bar & $\mathrm{MPa}$ & 10 \\
0.001 & $\mathrm{cbar}$ & $\mathrm{MPa}$ & 1000 \\
0.3048 & $\mathrm{ft}$ & $\mathrm{m}$ & 3.2808 \\
0.0929 & $\mathrm{ft}^{2}$ & $\mathrm{~m}^{2}$ & 10.7639 \\
3.7854 & gal & $\mathrm{L}$ & 0.2642 \\
2.54 & inch $(\mathrm{es})$ & $\mathrm{cm}$ & 0.3937 \\
25.4 & inch $(\mathrm{es})$ & $\mathrm{mm}$ & 0.0394 \\
1.7300 & $\mathrm{oz} / \mathrm{inch}^{3}$ & $\mathrm{~g} \cdot \mathrm{cm}^{-3}$ & 0.5780 \\
$\left({ }^{\circ} \mathrm{F}-32\right) \div 1.8$ & ${ }^{\circ} \mathrm{F}$ & ${ }^{\circ} \mathrm{C}$ & $\left(1.8 \times{ }^{\circ} \mathrm{C}\right)+32$
\end{tabular}


measuring soil water. This technology reduces the problems inherent in gypsum blocks (i.e., loss of contact with the soil by dissolving and inconsistent pore size distribution) by use of a mostly insoluble granular fill material held in a fabric tube supported in a metal or plastic screen. GMS operates on the same electrical resistance principle as gypsum blocks and contains a wafer of gypsum imbedded in the granular matrix below a pair of coiled wire electrodes. The electrodes are embedded in the granular fill material above the gypsum wafer. The gypsum wafer slowly dissolves to buffer the effect of salinity of the soil solution on electrical resistance between the electrodes. Watermark blocks operate under drier conditions than tensiometers as maximum readings range to $-200 \mathrm{cbar}$, and this characteristic makes them particularly appropriate for irrigation scheduling (Hanson et al., 2000).

Leaf water potential $\left(\Psi_{1}\right)$ measured at different times of the day (predawn and during the day) is often used to determine plant water status. Leaf water potential measured at predawn $\left(\Psi_{\mathrm{pd}}\right)$, when leaf stomata are closed, has been found to be significantly related to soil water status in grapevine under various crop conditions (Deloire et al., 2004; Medrano et al., 2003; van Leeuwen et al., 2001; Yuste et al., 1999). However, Williams (2002) pointed out that $\Psi_{\mathrm{pd}}$ does not accurately reflect vine water status under water stress because non-irrigated plants sometimes have similar values to their irrigated counterparts due to rehydration during the night. Thus, leaf water potential measured at midday $\left(\Psi_{\mathrm{md}}\right)$ would be better correlated to plant water status, plant performance, and soil water availability than $\Psi_{\text {pd }}$ (Williams and Araujo, 2002; Williams and Trout, 2005). Girona et al. (2006) showed that scheduling irrigation according to a certain $\Psi_{\text {md }}$ threshold improved irrigation effectiveness. Intrigliolo and Castel (2006) concluded that stem water potential and $g_{S}$ measured in the early morning were the best water stress indicators. Also, Cifré et al. (2005), Dry and Loveys (1999), and Medrano et al. (2003) recommended $g_{s}$ to evaluate grapevine water stress because of the fast response to soil water deficit and the good correlation to soil water content.

Baeza et al. (2007), Cuevas et al. (2006), Flexas et al. (2002), Lakso (1985), and Williams et al. (1994) established significant relationships between leaf water potential and leaf assimilation rate or $y_{S}$, indicating a sensitive response of leaf performance to its water status. Optimal irrigation scheduling using soil moisture sensors requires accurate threshold values for individual crops in given agricultural systems (Thompson et al., 2007). The objective of this work was to determine a functional relationship between soil water availability and grapevine water status to define a threshold value of soil matric potential for irrigation management.

\section{Materials and methods}

PLANT MATERIAL AND EXPERIMENTAL SITE. This work was carried out in the experimental fields of Universidad Politécnica de Madrid, Spain (lat. $40^{\circ} 26^{\prime} 36^{\prime \prime} \mathrm{N}$, long. $3^{\circ} 44^{\prime} 18^{\prime \prime} \mathrm{W}$, altitude $595 \mathrm{~m}$ ) over two consecutive growing seasons (2001-02). Measurements were taken on a 13-year-old vineyard of 'Tempranillo' grafted onto Richter 110 (110R). Plant spacing was $2 \mathrm{~m}$ between rows and $1.2 \mathrm{~m}$ within the plants along the row. Vines were trained to a vertical shoot positioned trellis (VSP) on a bilateral cordon oriented north-south. The experimental site was flat with $1.2 \mathrm{~m}$ deep homogeneous sandy loam soil. Field capacity and wilting point were field determined by tracking the soil water content trend along several years using a TDR [Trase System 6050XI; Soil Moisture Equipment, Santa Barbara, CA (Cuevas et al., 2006)]. Field capacity was $26.7 \%$ (v/v) corresponding to a soil matric potential of -0.024 $\mathrm{MPa}$, and wilting point was $9.6 \%$ (v/ v) corresponding to $-1.5 \mathrm{MPa}$. Soil total available water was about 172 $\mathrm{mm} \cdot \mathrm{m}^{-1}$, with a bulk density of 1.4 $\mathrm{g} \cdot \mathrm{cm}^{-3}$. Rooting depth was $1.2 \mathrm{~m}$, with a root density of $13 \%$ between 0 and $0.2 \mathrm{~m}$ depth, $53 \%$ between 0.2 and $0.6 \mathrm{~m}$ depth, and $34 \%$ between 0.6 and $1.2 \mathrm{~m}$ depth (data not published).

Thirty-minute averages of air temperature, reference evapotranspiration [ETo (Allen et al., 1998)], and total rainfall were continuously recorded with an automatic weather station located at the experimental vineyard (Table 1 ). The climate is typically Mediterranean, with a hot, dry period from mid-May to September.

IRRIGATION TREATMENTS AND EXPERIMENTAL DESIGN. A randomized complete block design with four replications was established. Each replicate consisted of three adjacent rows with 10 vines per row. The eight central vines on the central row were the data vines while the others served as borders. Since 1990, the irrigation system consisted of two $4 \mathrm{~L} \cdot \mathrm{h}^{-1}$ drippers per vine, $1.2 \mathrm{~m}$ apart. Weekly irrigation water to be applied (R) was calculated using the previous week's

Table 1. Monthly and annual meteorological data (2001-02) in Madrid, Spain. ETo = reference evapotranspiration (Allen et al., 1998), GDD = growing degree days [base temperature $10{ }^{\circ} \mathrm{C}\left(50.0{ }^{\circ} \mathrm{F}\right)$ ].

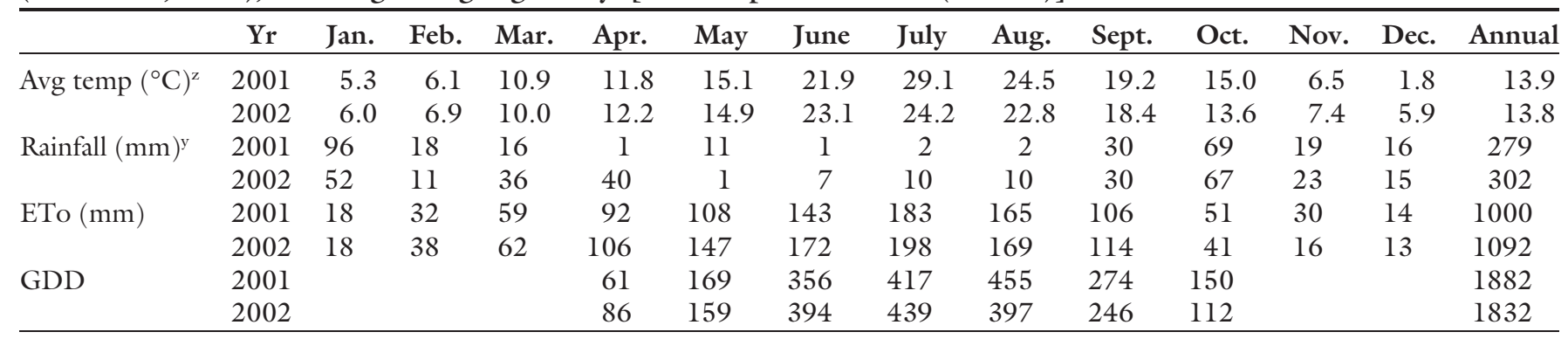

${ }^{\mathrm{z}}\left(1.8 \times{ }^{\circ} \mathrm{C}\right)+32={ }^{\circ} \mathrm{F}$.

${ }^{y} 1 \mathrm{~mm}=0.0394$ inch. 
ETo (Allen et al., 1998), effective rainfall, and a treatment coefficient using the following equation:

$$
\mathrm{R}=(\mathrm{Ti} \times \mathrm{ETo}-\mathrm{Pe}) \times 1 / 0.9
$$

where $\mathrm{Ti}$ is the treatment irrigation coefficient, Pe is the effective rainfall, and 0.9 is the efficiency of the irrigation system. Three deficit irrigation treatments were established: Tl replenished $45 \%$ of ETo, T2 replenished $30 \%$ of ETo, and T3 non-irrigated. The calculated irrigation amount was distributed over the next week on a daily basis. Only in 2001, after a steady trend of values under $20 \%$ of soluble solids, was irrigation increased in $\mathrm{Tl} \%$ to $100 \% \mathrm{ETo}$, and $\mathrm{T} 2 \%$ to $67 \%$ ETo, from day 248 to day 263 , corresponding to phenological stage 37 , berries not mature enough, according to Coombe (1995), to increase photosynthetic activity and enhance sugar accumulation. In 2002, the increase of sugar composition of berries was adequate and it was not necessary to increase the irrigation dose. Total water applied in 2001 and 2002 was 288 and $229 \mathrm{~mm}$ for $\mathrm{Tl}$, and 200 and $136 \mathrm{~mm}$ for T2. Following Hardie and Martin (2000), irrigation started when elongation of shoots stopped (day 159 in 2001, and day 185 in 2002), and ended when autumn rainfalls started (day 263 in 2001, and day 286 in 2002).

Measurements. Soil water potential $\left(\Psi_{\mathrm{m}}\right)$ was measured on a weekly basis from flowering to harvest with GMS (Watermark ${ }^{\circledR}$ ). This is an inexpensive, fast, and easy-to-use method, providing the opportunity for automatic recording in a Watermark ${ }^{\circledR}$ Monitor Datalogger. The equation used to convert soil electrical conductivity (EC) on soil matric potential was provided by the manufacturer. Sensors, operating within a range of -0.01 to $-0.2 \mathrm{MPa}$ (Charlesworth, 2000), were located at $0.3 \mathrm{~m}\left(\Psi_{0.3}\right), 0.6 \mathrm{~m}\left(\Psi_{0.6}\right)$, and $1.2 \mathrm{~m}\left(\Psi_{1.2}\right)$ depths in all replicates and treatments. One single vine per elemental plot was chosen to place the three soil sensors. Thus, there were three sensors per treatment and depth placed at the vine row at $0.25 \mathrm{~m}$ from the emitters and $0.35 \mathrm{~m}$ apart from the trunk, under the influence of the soil wetted volume. Data were collected with a hand-held soil moisture meter (Watermark ${ }^{\circledR}$, model 30KTCD).
Measurements were taken $1 \mathrm{~d}$ after irrigation events and on the same days of plant physiological evaluations. Because rooting was $1.2 \mathrm{~m}$ depth, soil profile matric potential $\left(\Psi_{0-1.2}\right)$ was calculated as a weighted by depth increment average of the soil water potential measured at each of the three depth intervals.

Stomatal conductance and leaf water potential were measured on the same leaf once every 2 weeks, from days of the year (DOY) 157 to 262 in 2001, and from DOY 164 to 280 in 2002. Six mature, sunlit, healthy leaves per treatment distributed between the four replications were sampled from the cluster area of main shoots. On each leaf, $g_{s}$ was determined and it was then covered with a plastic bag and excised to measure the leaf water potential. Stomatal conductance was evaluated in the early morning from 0800 to 0900 $\mathrm{HR}\left(\mathrm{gs}_{\mathrm{em}}\right)$, and at midday [from 1130 to $\left.1230 \mathrm{HR}\left(\mathrm{gs}_{\mathrm{md}}\right)\right]$ using a portable, open-system, gas exchange analyzer (LI-6400; LI-COR, Lincoln, NE). Leaf water potential measurements were made with a pressure chamber (Soil Moisture Equipment) according to Turner's (1988) procedure. Measurements were done at predawn from 0300 to $0400 \mathrm{HR}\left(\Psi_{\mathrm{pd}}\right)$, at early morning from 0800 to $0900 \mathrm{HR}$ $\left(\Psi_{\mathrm{em}}\right)$, and at midday [from 1130 to 1230 HR $\left.\left(\Psi_{\text {md }}\right)\right]$.

Leaf area surface was performed based on Carbonneau (1976) by establishing a relationship between main leaf vein and surface area. Eight shoots per treatment were tagged in each single plot and the main leaf vein was measured on one of every three leaves on main and lateral shoots. The relationship between the main leaf vein $(\mathrm{Ln})$ and the leaf surface (Ls) was: $\mathrm{Ls}=\mathrm{Ln} \times 20.306-69.302$.

Statistical analysis. Analysis of variance was performed using SPSS (version 11.0; SPSS, Chicago). Duncan's test $(P<0.05)$ was used to compare differences among means.
The regression slopes were compared by using the software package MSTAT-C (version 2.1.0; Michigan State University, East Lansing).

\section{Results}

ENVIRONMENTAL CONDITIONS AND VINE PHENOLOGY. In both years (Table 1), July was the hottest month, with a mean temperature of $29.1^{\circ} \mathrm{C}$ in 2001 and $24.2^{\circ} \mathrm{C}$ in 2002 . During the growing season (budbreak to harvest), rainfall was 47 and $116 \mathrm{~mm}$ in 2001 and 2002, mostly concentrated a few days before harvest. Reference evapotranspiration totaled 904 and $848 \mathrm{~mm}$ in the 2001 and 2002 growing seasons. Therefore, most water required for crop transpiration was provided by deficit irrigation and/or soil water storage, depending on treatments. On a daily basis, the highest ETo occurred in July, with 5.9 $\mathrm{mm} \cdot \mathrm{d}^{-1}$ in 2001 and $6.4 \mathrm{~mm} \cdot \mathrm{d}^{-1}$ in 2002.

Budburst, flowering, veraison, and harvest were on DOY 85, 157, 198 , and 277, respectively, in 2001, and on DOY 99, 151, 213, and 287 in 2002 (Table 2). Warmer temperatures in Apr. 2002 resulted in earlier vine growth and flowering compared with 2001. Very hot temperatures in July 2001 accelerated crop development compared with 2002. Veraison stage was reached 2 weeks earlier in 2001 than in 2002. These phenological differences had limited impact on canopy size. In 2001, average leaf area per unit soil surface area at veraison for $\mathrm{T} 1, \mathrm{~T} 2$, and $\mathrm{T} 3$ treatments were $2.5,2.5$, and $1.8 \mathrm{~m}^{2} \cdot \mathrm{m}^{-2}$; and in 2002 were $2.3,2.4$, and $1.3 \mathrm{~m}^{2} \cdot \mathrm{m}^{-2}$, respectively.

SEASONAL PATTERNS OF SOIL MATRIC POTENTIAL, LEAF WATER POTENTIAL, AND Gs. Soil matric potential showed different trends in response to irrigation treatments (Fig. 1). Larger differences were observed in upper soil layers, indicating more water extraction associated with more abundant root density (data not

Table 2. Day of the year (DOY) at which the key phenological events (Coombe, 1995) took place in 2001 and 2002 growing seasons in 'Tempranillo' wine grapevine located in Madrid, Spain.

\begin{tabular}{lcccc}
\hline & Budburst & Flowering & Veraison & Harvest \\
\cline { 2 - 5 } Yr & \multicolumn{5}{c}{ DOY } \\
\hline 2001 & 95 & 157 & 198 & 277 \\
2002 & 99 & 151 & 213 & 287 \\
\hline
\end{tabular}


DOY 2001

150160170180190200210220230240250260270

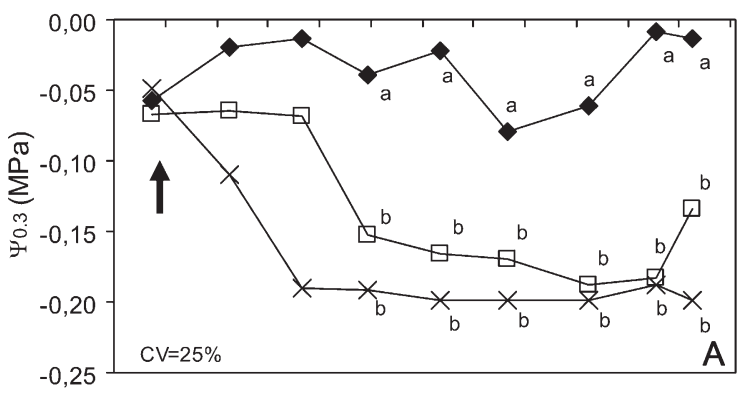

150160170180190200210220230240250260270

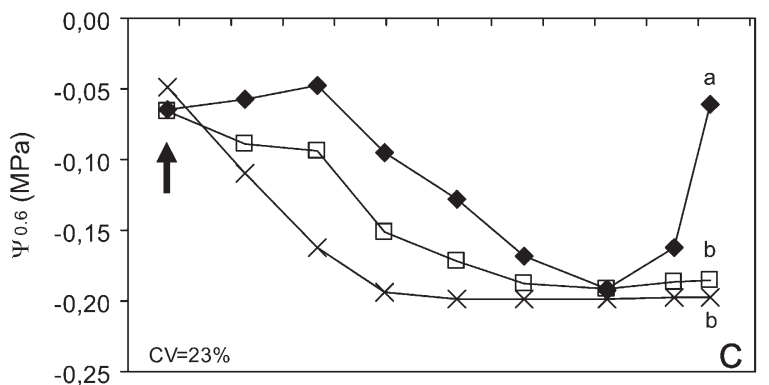

150160170180190200210220230240250260270

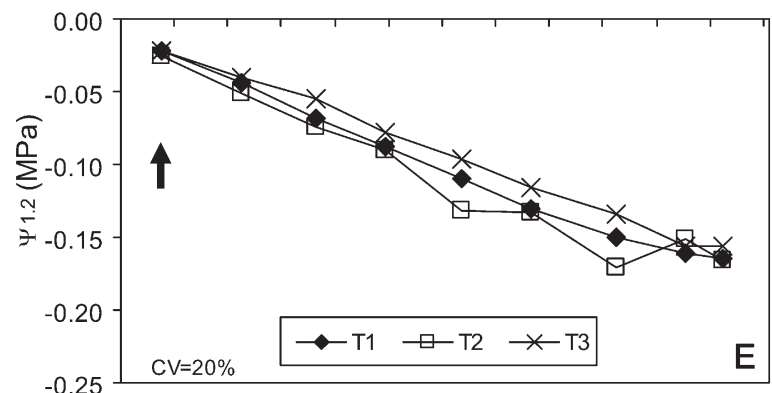

DOY 2002

150160170180190200210220230240250260270

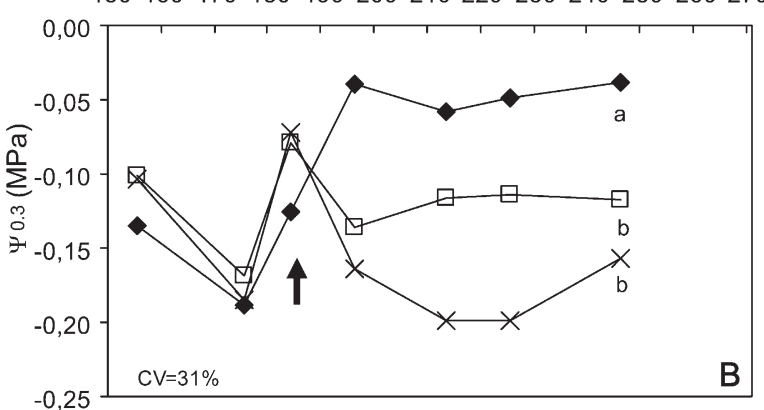

150160170180190200210220230240250260270

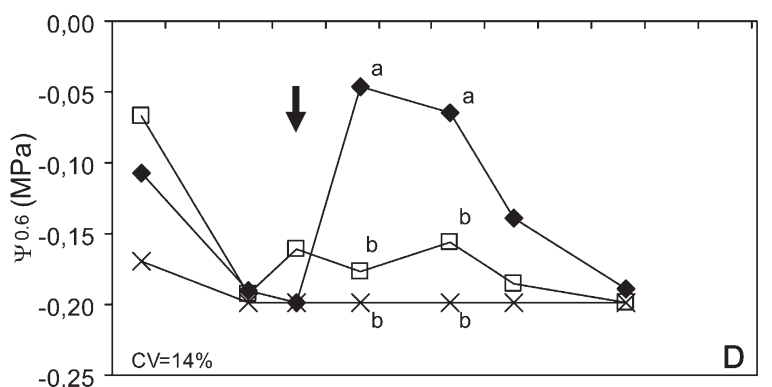

150160170180190200210220230240250260270

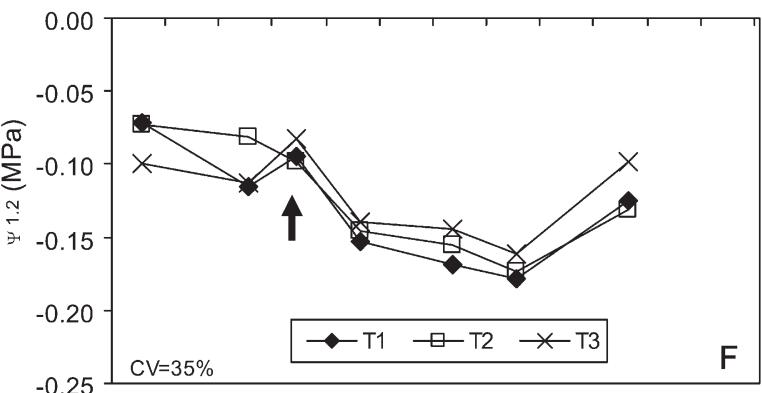

Fig. 1. Seasonal evolution of soil matric potential measurements for T1 [45\% reference evapotranspiration (ETo)], T2 (30\% ETo), and T3 (non-irrigation) in a vineyard with sensors at (A and B) $0.3 \mathrm{~m}\left(\Psi_{0.3}\right),\left(\mathrm{C}\right.$ and D) $0.6 \mathrm{~m}\left(\Psi_{0.6}\right)$, and (E and F) $1.2 \mathrm{~m}$ $\left(\Psi_{1.2}\right)$ depths during 2001 (left) and 2002 (right). Arrows indicate the beginning of irrigation. Each point represents the average of three measurements. Treatments with the same letter are not significantly different by Duncan's test at $P<0.05$. $\mathrm{DOY}=$ day of year, $\mathrm{CV}=$ average $\mathrm{cv} ; 1 \mathrm{MPa}=10$ bars.

shown). Irrigation replenished water consumed only in the upper layer $(0-30 \mathrm{~cm})$ of T1. In deeper soil layers (60 and $120 \mathrm{~cm}$ ), a consistent decrease across treatments in soil water potential as the season progressed indicated significant root water uptake and no water refill due to irrigation. $\mathrm{T} 1$ and T2 were deficit irrigation strategies.

Evaluations of leaf water potential at predawn $\left(\Psi_{\text {pd }}\right)$ detected differences in water supply between irrigated and non-irrigated treatments. In the nonirrigated treatment (T3), $\Psi_{\text {pd }}$ were lower starting at 4 and 2 weeks after the beginning of irrigation in 2001 and 2002, respectively (Fig. 2, A and B). In both years, the differences between treatments became significant when $\Psi_{\text {pd }}$ in T3 was lower than -0.4 $\mathrm{MPa}$. The lowest $\Psi_{\mathrm{pd}}$ values reached in $\mathrm{T} 1, \mathrm{~T} 2$, and $\mathrm{T} 3$ were $-0.33,-0.52$, and $-1.04 \mathrm{MPa}$ in 2001 and -0.50 , -0.52 , and $-0.87 \mathrm{MPa}$ in 2002 .

In both seasons, significant differences were found in $\Psi_{\mathrm{em}}$ (Fig. 2, C and D) and $\Psi_{\text {md }}$ (Fig. 2, E and F) between irrigated and non-irrigated treatments. The lowest $\Psi_{\mathrm{em}}$ values reached by $\mathrm{T} 1, \mathrm{~T} 2$, and $\mathrm{T} 3$ were $-1.16,-1.46$, and $-1.91 \mathrm{MPa}$ in 2001 and $-1.38,-1.51$, and -1.55 $\mathrm{MPa}$ in 2002 . The lowest $\Psi_{\mathrm{md}}$ values reached by $\mathrm{T} 1, \mathrm{~T} 2$, and $\mathrm{T} 3$ were $-1.32,-1.38$, and $-1.98 \mathrm{MPa}$ in 2001 and $-1.52,-1.59$, and -1.77 $\mathrm{MPa}$ in 2002. The variability of $\Psi_{\mathrm{pd}}$ measurements was always greater than $\Psi_{\mathrm{em}}$ and $\Psi_{\text {md }}$ measurements in
2001 and 2002 . The $\mathrm{CV}$ of $\Psi_{\mathrm{pd}}$ was $34 \%$ in 2001 and $12 \%$ in 2002, while the $\mathrm{CV}$ of $\Psi_{\mathrm{em}}$ and $\Psi_{\mathrm{md}}$ was $7 \%$ and $8 \%$ in 2001 , and $11 \%$ and $9 \%$ in 2002 .

Stomatal conductance was much lower in 2002 than in 2001 by the time irrigation began (Fig. 3). After irrigation started in $2001, \mathrm{gs}_{\mathrm{em}} \mathrm{de}-$ creased throughout the season in all treatments (Fig. 3A). However, the largest decrease was observed in T3. Differences in $\mathrm{gs}_{\mathrm{em}}$ between irrigated and non-irrigated treatments began to appear 4 weeks after irrigation was triggered. Within the irrigated treatments, T1 had significantly $(P<0.05)$ higher $\mathrm{gs}_{\mathrm{em}}$ values than T2 for 2 weeks after veraison (DOY 198), after which similar values were observed. The lowest values of $\mathrm{gs}_{\mathrm{em}}$ in 2001 
DOY 2001

150160170180190200210220230240250260270

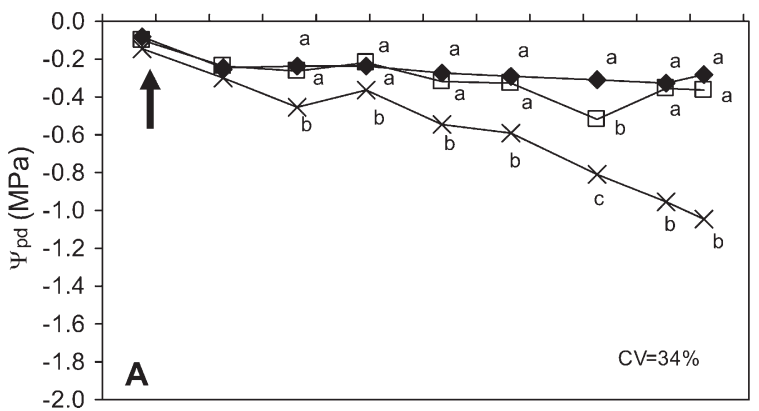

150160170180190200210220230240250260270

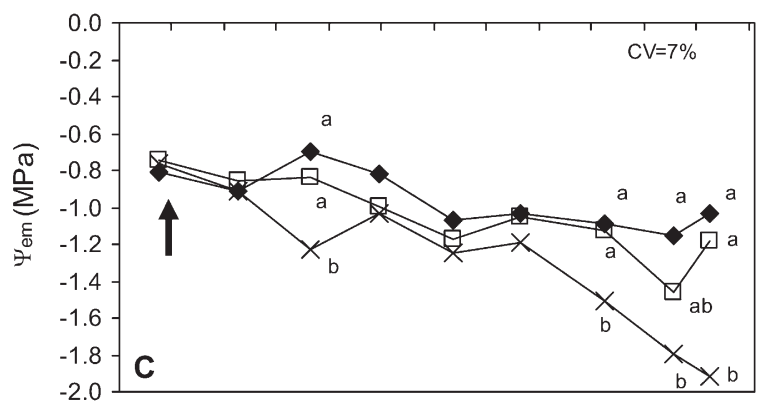

150160170180190200210220230240250260270

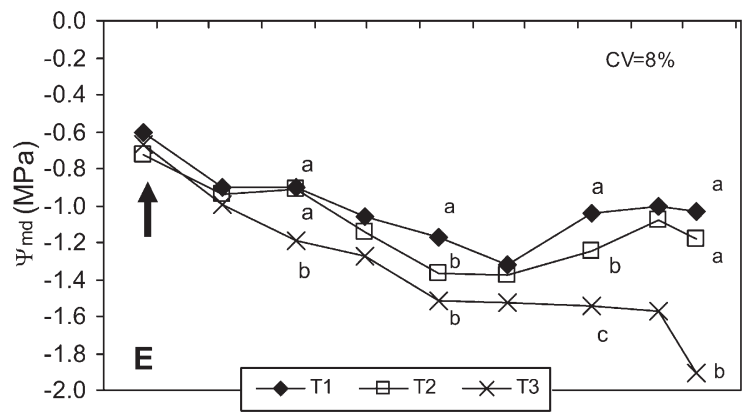

DOY 2002

150160170180190200210220230240250260270

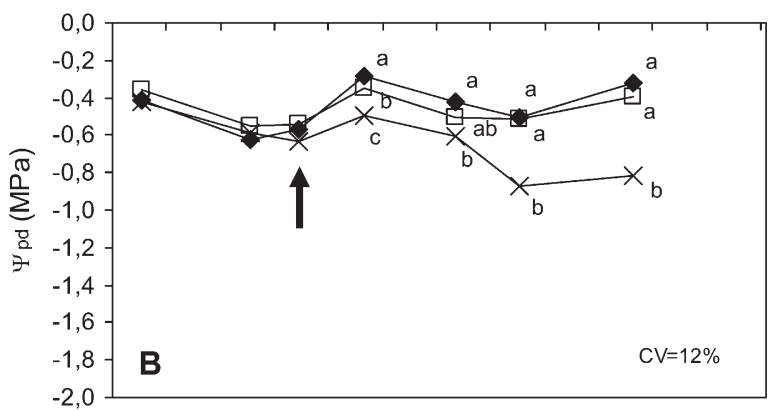

$\begin{array}{lllllllllllll}150 & 160 & 170 & 180 & 190 & 200 & 210 & 220 & 230 & 240 & 250 & 260 & 270\end{array}$
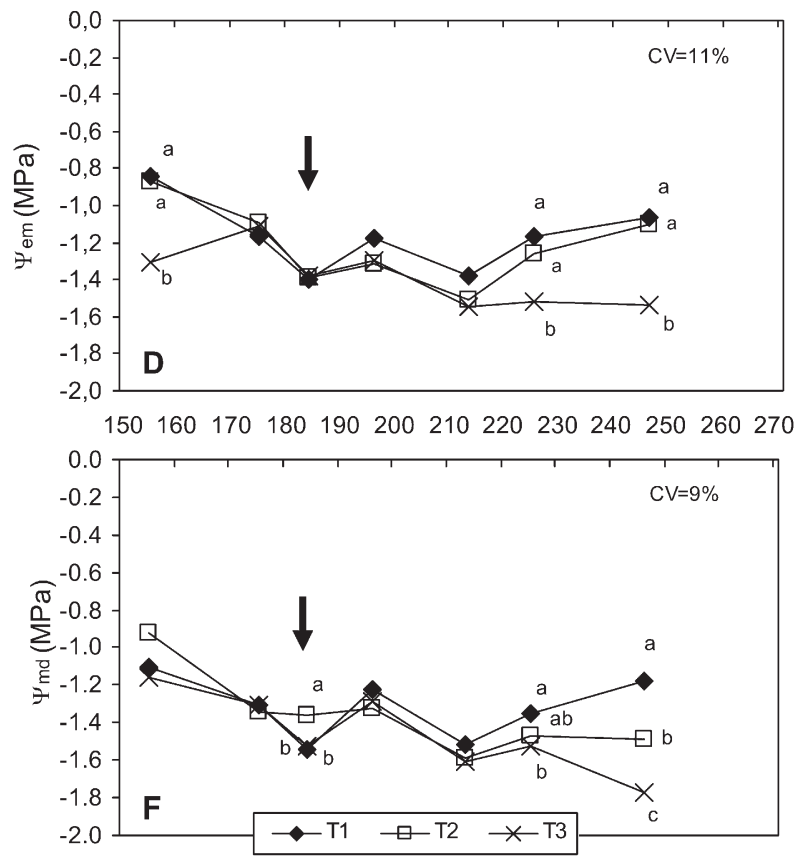

Fig. 2. Seasonal evolution of grapevine leaf water potential measured at (A and B) predawn ( $\left.\Psi_{\text {pd }}\right),(C$ and $D)$ early morning $\left(\Psi_{\mathrm{em}}\right)$, and (E and F) midday ( $\left.\Psi_{\mathrm{md}}\right)$ during 2001 (left) and 2002 (right), for T1 [45\% reference evapotranspiration (ETo)], T2 (30\% ETo), and T3 (non-irrigated) treatments. Each point represents the average of six determinations. Treatments with the same letter are not significantly different by Duncan's test at $P<0.05$. Arrows indicate the beginning of irrigation. DOY $=$ day of year, $\mathrm{CV}=$ average $\mathrm{CV} ; 1 \mathrm{MPa}=10$ bars.

were 51.4 and $14.3 \mathrm{mmol} \cdot \mathrm{m}^{-2} \cdot \mathrm{s}^{-1}$ in irrigated and non-irrigated treatments, respectively. In 2002, $\mathrm{gs}_{\mathrm{em}}$ decreased in all treatments until irrigation started when, unlike the previous year, $\mathrm{gs}_{\mathrm{em}}$ increased in Tl until the end of the cycle. Significant differences in $\mathrm{gs}_{\mathrm{em}}$ were found between $\mathrm{Tl}$ and the rest of the treatments. In $\mathrm{T} 3, \mathrm{gs}_{\mathrm{em}}$ decreased mainly after veraison (DOY 213) (Fig. 3B). The lowest $\mathrm{gs}_{\mathrm{em}}$ values in 2002 were 63.2 and $25.6 \mathrm{mmol} \cdot \mathrm{m}^{-2} \cdot \mathrm{s}^{-1}$ in irrigated and non-irrigated treatments, respectively (Fig. 3B).

Observations at midday ( $\left.\mathrm{gs}_{\mathrm{md}}\right)$ provided a complementary picture. In 2001, significant differences in $\mathrm{gs}_{\mathrm{md}}$ between $\mathrm{T} 1$ and $\mathrm{T} 2$ were observed throughout the season. However, in 2002 , stomata at noon were mostly closed in all treatments through the season. The lowest $\mathrm{gs}_{\mathrm{md}}$ values were 29 and $14.8 \mathrm{mmol} \cdot \mathrm{m}^{-2} \cdot \mathrm{s}^{-1}$ in 2001 and 21.7 and $11.9 \mathrm{mmol} \cdot \mathrm{m}^{-2} \cdot \mathrm{s}^{-1}$ in 2002 in irrigated and non-irrigated treatments, respectively. Calculated $\mathrm{CV}$ indicated high variability in the measurements, with lower $\mathrm{CV}$ in $\mathrm{gs}_{\mathrm{em}}$ (35\% in 2001 and $38 \%$ in 2002 ) than in $\mathrm{gs}_{\mathrm{md}}(42 \%$ in 2001 and $49 \%$ in 2002).

ReLationship BETWEen SOIL MATRIC POTENTIAL AND PLANT WATER STATUS. The relation between whole profile soil matric potential and vine water status as determined by leaf water potential and $g_{S}$ was examined.
Because Watermark ${ }^{\circledR}$ sensors provide reliable outputs within the range of -0.01 to $-0.2 \mathrm{MPa}$, we included in our analysis only the values of soil matric potential from irrigated treatments (Tl and T2). Soil matric potentials $\left(\Psi_{0-1.2}\right)$ ranged between -0.04 and $-0.18 \mathrm{MPa}$ (Figs. 4 and $5)$, and leaf water potentials $\left(\Psi_{\mathrm{pd}}\right.$, $\Psi_{\mathrm{em}}$, and $\left.\Psi_{\mathrm{md}}\right)$ between -0.08 and $-1.91 \mathrm{MPa}$ (Fig. 4). $\Psi_{0-1.2}$ was significantly related to plant water status in 2001 and 2002 (Figs. 4A and B, and 5 ). No differences were detected between regression lines at early morning and midday, so only one regression line with all pooled data are shown for leaf water potential (Fig. 4B). The regression lines of $g s$ 

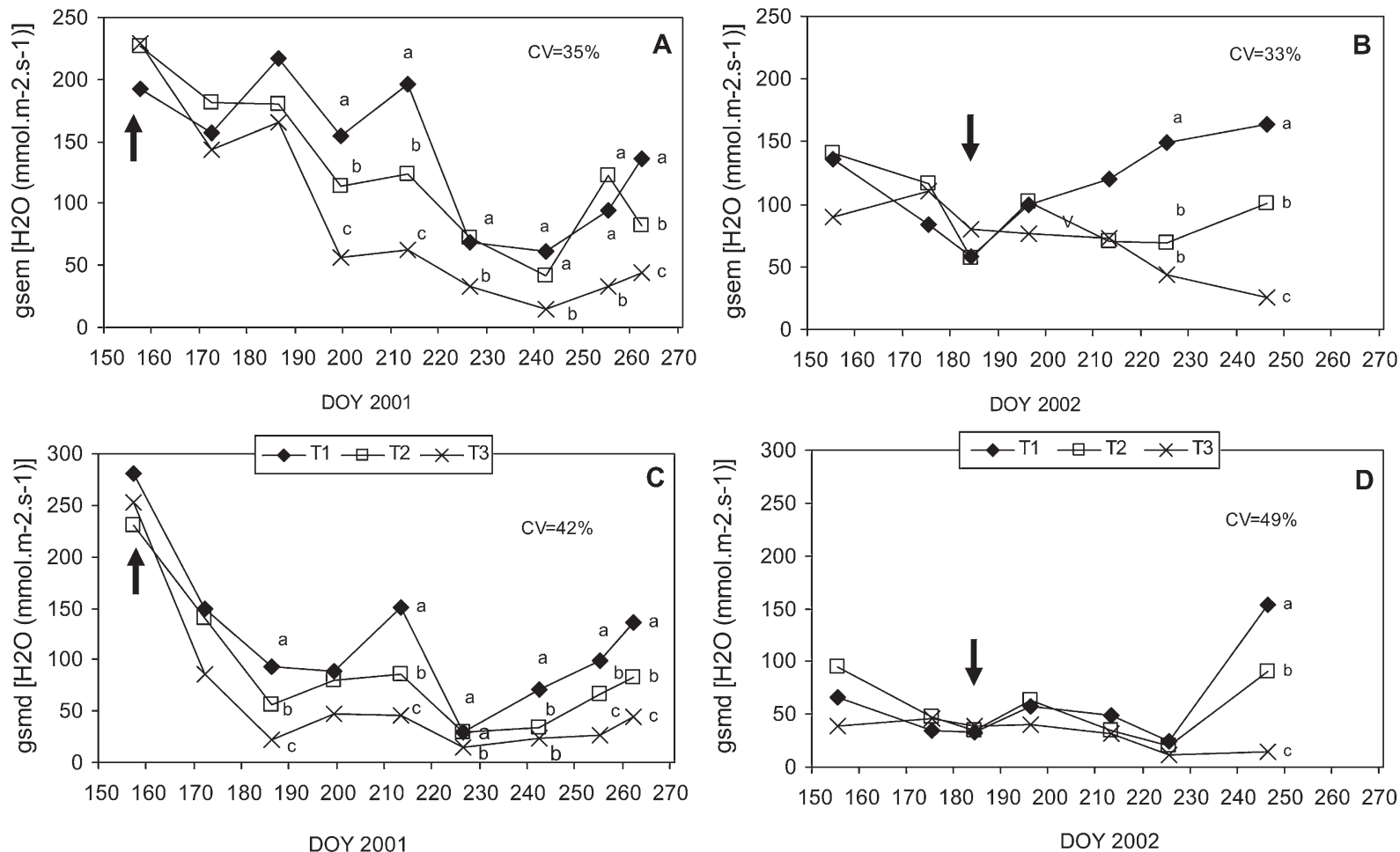

Fig. 3. Seasonal evolution of grapevine stomatal conductance (gs) measured (A and B) early morning (gs $\mathrm{em}_{\mathrm{em}}$ ) $\mathrm{gnd}_{\mathrm{C}}$ and D) midday ( $\mathrm{gs}_{\mathrm{md}}$ ) during 2001 (left) and 2002 (right) for T1 [45\% reference evapotranspiration (ETo)], T2 (30\% ETo), and T3 (non-irrigated) treatments. Each point represents the average of six measurements. Treatments with the same letter are not significantly different by Duncan's test at $P<0.05$. Arrows indicate the beginning of irrigation. DOY $=$ day of year, $\mathrm{CV}$ = average $\mathrm{CV}$.

at early morning and midday were different $(P<0.05)$ in intercept but not in slope (Fig. 5$). \Psi_{0-1.2}$ was better correlated to $\Psi_{\mathrm{em}}$ and $\Psi_{\mathrm{md}}\left(\mathrm{r}^{2}=0.50\right.$, Fig. $4 \mathrm{~B})$ than to $\Psi_{\mathrm{pd}}\left(\mathrm{r}^{2}=0.43\right.$, Fig. $4 \mathrm{~A})$. In both seasons, $\Psi_{0-1.2}$ was also significantly related to $\mathrm{gs}_{\mathrm{em}}$ and $\mathrm{gs}_{\mathrm{md}}$ $\left(\mathrm{r}^{2}=0.59\right.$ and 0.44 , respectively; Fig. 5).

\section{Discussion}

The purpose of this research was to determine if there was a functional relationship between soil water availability and grapevine water status that could be used to effectively manage deficit irrigation. One of the simplest methods to estimate vine water status would be to monitor soil water (Intrigliolo and Castel, 2006) under the assumption that a functional relationship links both system components. Although the method neglects the impact of atmospheric demand on plant evapotranspiration, it assumes there is a soil water threshold value at which irrigation should be applied to prevent major crop water stress. In this work, we measured soil water potential with Watermark ${ }^{\circledR}$ sensors located at $0.3,0.6$, and $1.2 \mathrm{~m}$ depths. These sensors are inexpensive and easy-to-use, but have a limited range of response from -0.01 to $-0.2 \mathrm{MPa}$ (Charlesworth, 2000). This range was found to be adequate for our deficit irrigation application (Fig. 1).

Sensors at the $0.3 \mathrm{~m}$ depth detected variations in soil water content

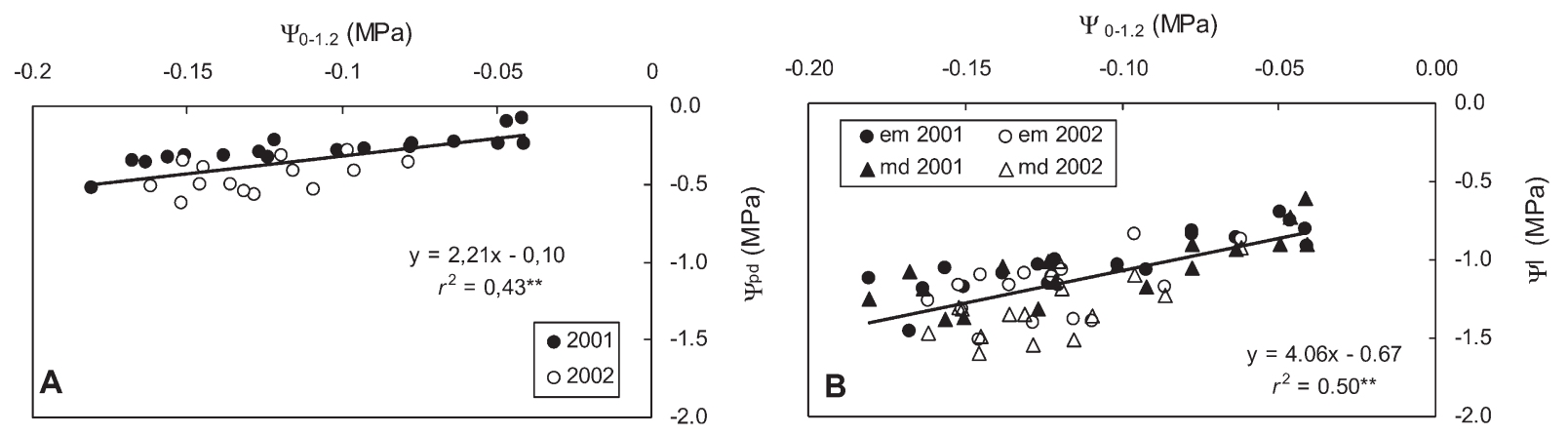

Fig. 4. The relationship between average soil matric potential in the soil profile $\left(\Psi_{0-1.2}\right)$ and grapevine leaf water potential ( $\left.\Psi_{1}\right)$ at $(A)$ predawn $\left(\Psi_{\mathrm{pd}}\right)$, and $(\mathrm{B})$ early morning $(\mathrm{em})$ and midday $(\mathrm{md})$ in 2001 and 2002 . Each point represents the average of six measurements. Coefficients of determination $\left(r^{2}\right)$ were significant at $P=0.01(* *) .1 \mathrm{MPa}=10 \mathrm{bars}$. 


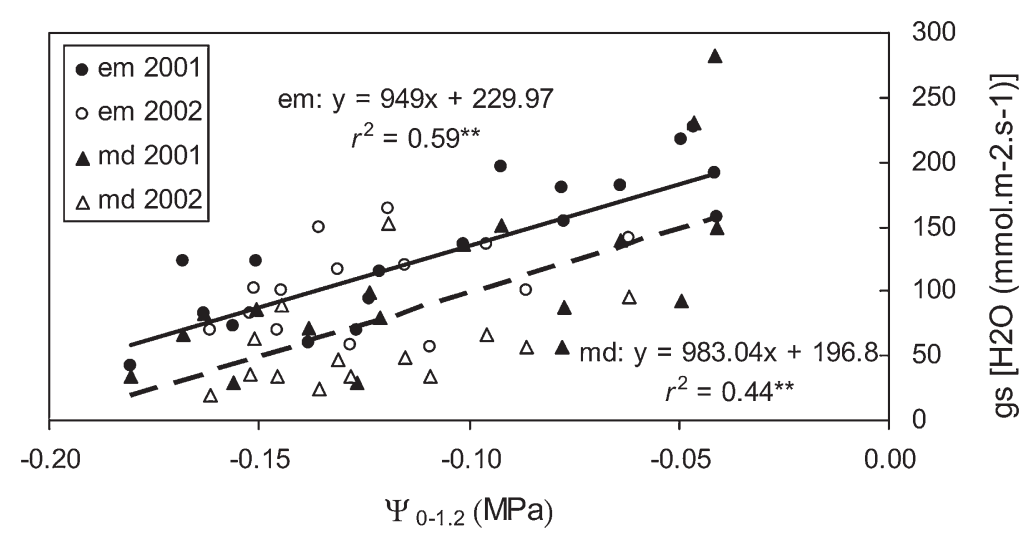

Fig. 5. The relationship between average soil matric potential in the soil profile ( $\left.\Psi_{0-1.2}\right)$ and grapevine stomatal conductance (gs) measured in the early morning (em) and at midday (md) in 2001 and 2002. Each point represents the average of six measurements. Coefficients of determination $\left(r^{2}\right)$ were significant at $P=0.01\left(^{* *}\right) .1 \mathrm{MPa}=10$ bars.

earlier than sensors located at deeper soil layers. As a result, continuous variations were observed in the $\Psi_{0.3}$ readings (Fig. 1, A and B). Sensors at the $0.6 \mathrm{~m}$ depth registered a steady decrease in $\Psi_{0.6}$ compared with those at the $0.3 \mathrm{~m}$ depth (Fig. $1, \mathrm{C}$ and $\mathrm{D}$ ), possibly due to the high root density and more intense water extraction at this depth. Prior and Grieve (1986) recommended that $\Psi_{0.6}$ should not fall under $-0.05 \mathrm{MPa}$ to prevent water stress, particularly in the weeks immediately after flowering, when plants are more sensitive to stress. Myburgh (2003) considered water stress when soil matric potential was lower than $-0.07 \mathrm{MPa}$. According to these authors, all of our treatments remained under water stress conditions through both growing seasons, although in $2001, \Psi_{0.6}$ maintained values higher than $-0.07 \mathrm{MPa}$ for $30 \mathrm{~d}$ after flowering.

$\Psi_{1.2}$ was unaffected by irrigation (Fig. 1, E and F). Soil moisture pattern at this depth was similar across treatments and indicated a slow and consistent reduction in soil water. The trend of soil moisture at this depth is usually influenced by water movement to upper layers, where abundant roots extract considerable amounts of water. However, the lack of treatment effect suggested that capillary rise might have not been the main cause for the soil moisture trends observed at this depth.

Leaf water potential evaluated at predawn hours $\left(\Psi_{\text {pd }}\right)$ was within the range of -0.08 and $-0.63 \mathrm{MPa}$ in the irrigated treatments. Because most readings were higher than -0.54
MPa (Fig. 2, A and B), our irrigated vines were under conditions of moderate water stress (Deloire et al., 2004; Intrigliolo and Castel, 2006; Medrano et al., 2003). Contrary to irrigated vines, values for nonirrigated vines were lower than -0.6 MPa during significant portions of the season, which is considered severe water stress (Deloire et al., 2004). Recorded $\Psi_{\mathrm{em}}$ and $\Psi_{\mathrm{md}}$ values were lower in 2002 (Fig. 2, D and F) than in 2001 (Fig. 2, C and E). In 2002, irrigation began later and plants were under greater water stress when irrigation started $\left(\Psi_{\mathrm{md}}=-1.52 \mathrm{MPa}\right)$ than in 2001 ( $\left.\Psi_{\mathrm{md}}=-0.72 \mathrm{MPa}\right)$. As the season progressed, stress conditions accumulated, resulting in larger differences among treatments. The development of $\Psi_{\mathrm{em}}$ and $\Psi_{\mathrm{md}}$ suggested that both of these measurements were good indicators of the effect of irrigation on plant water status. However, they were not adequate at detecting the sufficiency of water applied because no differences were found between $\mathrm{T} 1$ and $\mathrm{T} 2$ in spite of $33 \%$ more water applied in T1. Intrigliolo and Castel (2006) obtained differences in $\Psi_{\mathrm{pd}}$ and $\Psi_{\text {stem }}$ at early morning between vines under moderate and severe water stress, but no differences were found in $\Psi_{\mathrm{md}}$. However, Grimes and Williams (1990) and Araujo et al. (1995) observed a greater decrease in $\Psi_{\mathrm{md}}$ in the most severely stressed treatments compared with the mildly stressed treatments. Differences between these results might be mainly due to the level of plant water deficit because under intense water stress, variations in leaf water potential are mostly detected at early morning when stomata are open. Under our deficit irrigation conditions, severe water stress is prevented but vines are subjected to controlled water deficit most of the year.

Stomatal conductance was the only measured parameter able to distinguish the effect of irrigation treatments, especially the early morning evaluations (Fig. 3, A and B). Although differences in stomatal response were found between years, higher $g_{s}$ values were recorded in treatments where more water was applied through irrigation (Fig. 3). Highest stomatal closure was measured in mid-August after veraison (Table 2), which is in agreement with Intrigliolo and Castel (2006) who observed the same response in 'Tempranillo' plants subjected to water stress. In both seasons, larger variability was computed in $\mathscr{g}_{\mathrm{s}}$ measurements (CV about 40\%) than in leaf water potential measurements (about 13\%). Cifré et al. (2005) concluded that $g_{S}$ is the best indicator of water stress in grapevine because of the rapid response to water deficit. However, they pointed out that gs showed more variability than leaf water potential, possibly due to the effects of vapor pressure deficit or differences in light exposure of the leaves (Düring, 1976). The extreme conditions at midday produced a consistent decrease in $\mathrm{gs}_{\mathrm{m}}$ compared with $\mathrm{gs}_{\mathrm{em}}$, which evidenced the rapid stomatal regulation to avoid water loss, yet making these evaluations less recommended for the purpose of triggering irrigation.

Leaf water potential and $g_{S}$ were highly correlated to the weighted average matric potential of the soil profile $\left(\Psi_{0-1.2}\right)$ (Figs. 4 and 5$) . \Psi_{\mathrm{em}}$ and $\Psi_{\mathrm{md}}$ were slightly better correlated to $\Psi_{0-1.2}$ than $\Psi_{\text {pd }}$, which indicated that plant water status is more responsive to soil water availability when the atmospheric demand is high (Williams and Araujo, 2002; Yuste et al., 2004). However, Cifré et al. (2005), Deloire et al. (2004), and Yuste et al. (1999) obtained a good relationship between $\Psi_{\mathrm{pd}}$ and the water status of the fraction of soil explored by roots. The lower slope of the regression line between $\Psi_{0-1.2}$ and $\Psi_{\text {pd }}$ (Fig. 4A) indicated less variation in plant water status at predawn compared with plant water status after sunrise (Fig. 4B). Nadler and 
Heuer (1997) and Schultz (2003) also found that under severe water stress or when atmospheric demand sharply increased, leaf water potential remained relatively constant, in spite of large changes in soil matric potential. Stomata close during the night hours and shoot tissues recover from water deficit, thus no differences in $\Psi_{\text {pd }}$ were observed between irrigated and non-irrigated plants (Williams, 2002). After sunrise stomata opened and atmospheric demand increased, there was a more pronounced slope of the regression line without significant differences between early morning and midday evaluations (Fig. 4B). Similar responses have been reported when soil water status was evaluated as water content. Cuevas et al. (2006) found a good relationship between soil water content $(\theta \mathrm{v})$ up to $1.1 \mathrm{~m}$ depth and $g_{s}$, and Williams and Trout (2005) and Naor et al. (1994) determined a direct relationship between $\theta \mathrm{v}$ and $\mathrm{gs}_{\mathrm{md}}$.

Toome (2002) and Deloire et al. (2004) established that severe water deficit begins when soil matric potential falls under $-0.06 \mathrm{MPa}$. In our work, $\Psi_{0-1.2}$ values of $-0.06 \mathrm{MPa}$ corresponded to $\Psi_{\mathrm{pd}}$ and $\Psi_{\mathrm{em}} / \Psi_{\mathrm{md}}$ values of -0.23 and $-0.91 \mathrm{MPa}$, respectively, which agrees with Deloire et al. (2004) who consider these values as mild water stress. Similarly, Williams (2002) and Baeza et al. (2007) determined that $\Psi_{\text {md }}$ could drop down to $-1.1 \mathrm{MPa}$ without evidence of water deficit in vines. $\Psi_{0-1.2}$ values of $-0.06 \mathrm{MPa}$ corresponded to $\mathrm{gs}_{\mathrm{em}}$ and $\mathrm{gs}_{\mathrm{md}}$ values, respectively, of 173 and $138 \mathrm{mmol} \cdot \mathrm{m}^{-2} \cdot \mathrm{s}^{-1}$, which according to Cifré et al. (2005) is close to the lower limit of light water stress $\left(g_{s}>150\right.$ $\left.\mathrm{mmol} \cdot \mathrm{m}^{-2} \cdot \mathrm{s}^{-1}\right)$.

In the same experimental vineyard as that of the present work, Cuevas et al. (2006) fitted a logarithmic relationship between $g_{S}$ and net photosynthesis rate (A). In this relationship, the initial slope of A started decreasing at $g_{S}=35 \mathrm{mmol} \cdot \mathrm{m}^{-2} \cdot \mathrm{s}^{-1}$ and it leveled off at $g_{S}=175$ $\mathrm{mmol} \cdot \mathrm{m}^{-2} \cdot \mathrm{s}^{-1}$. Following these authors and considering $\Psi_{0-1.2}$, leaf water potential and $g_{S}$ relationships (Figs. 4B and 5), we found that when $\Psi_{0-1.2}>-0.04 \mathrm{MPa}$, plants have no soil water limitations; when $-0.04<$ $\Psi_{0-1.2}<-0.14 \mathrm{MPa}$, the soil water content falls within what is named water deficit $\left(\Psi_{\mathrm{md}}\right.$ and $\Psi_{\mathrm{em}}$ around
-1.0 to $-1.1 \mathrm{MPa}$ ), where vegetative growth is stopped at $-0.08 \mathrm{MPa}$, but $g_{s}$ rates allow medium to high photosynthesis rates (gs ranges within $\left.50-150 \mathrm{mmol} \cdot \mathrm{m}^{-2} \cdot \mathrm{s}^{-1}\right)$; and when $\Psi_{0-1.2}<-0.18 \mathrm{MPa}\left(g_{S}<50\right.$ and $\Psi_{\mathrm{md}}$ or $\Psi_{\mathrm{em}}$ around $\left.-1.4 \mathrm{MPa}\right)$ the soil water content is clearly limiting leaf physiological activities and plants would be into severe water stress conditions. Thus, it would be recommended to avoid soil matric potential falling to $-0.14 \mathrm{MPa}$.

Hardie and Martin (2000) proposed using shoot growth as an indicator to trigger irrigation. They found that shoot growth elongation stops at soil water potential around $-0.07 \mathrm{MPa}$, which equals $\Psi_{\mathrm{pd}}=-0.25$ and $\Psi_{\mathrm{md}}=-0.95 \mathrm{MPa}$ attending Fig. 4 equations. Williams (2002) recommends starting irrigation when $\Psi_{\text {md }}$ $\approx-1.0 \mathrm{MPa}$, when shoot growth rate is very slow. These former values correspond to $g_{\mathrm{S}}=146 \mathrm{mmol} \cdot \mathrm{m}^{-2} \cdot \mathrm{s}^{-1}$, which is within the range considered as mild water deficit (Cifré et al., 2005). We had previously determined under similar experimental conditions to those in this study (Baeza et al., 2007) that when shoot elongation totally stops, leaf water potentials had the following values: $\Psi_{\mathrm{pd}}=-0.48$, $\Psi_{\mathrm{em}}=-1.12$ and $\Psi_{\mathrm{md}}=-1.18 \mathrm{MPa}$. Substituting these values in the regressions shown in Fig. 4, thresholds for irrigation would be $\Psi_{0-1.2}=-0.17$ $\mathrm{MPa}$ if predawn measurements (Fig. $4 \mathrm{~A})$ were used or $\Psi_{0-1.2}=-0.12 \mathrm{MPa}$ if measurements at early morning or midday (Fig. 4B) were used.

$\Psi_{0-1.2}=-0.12 \mathrm{MPa}$ corresponds to a leaf water potential of $-1.16 \mathrm{MPa}$ (Fig. 4B) and $g_{S}$ of $116 \mathrm{mmol} \cdot \mathrm{m}^{-2} \cdot \mathrm{s}^{-1}$ at early morning and $79 \mathrm{mmol} \cdot \mathrm{m}^{-2} \cdot \mathrm{s}^{-1}$ at midday (Fig. 5), which are within the $g_{s}$ range assigned as moderate water deficit (Cifré et al., 2005). Using relationships developed previously in our laboratory under similar conditions, when $\Psi_{0-1.2}=-0.12 \mathrm{MPa}$, vines would be expected to have dropped leaf assimilation rate to $41 \%$ if the above $g_{S}$ is used (Cuevas et al., 2006) or to $45 \%$ if the leaf water potential is used (Baeza et al., 2007). This integrated soil water potential lowest threshold (i.e., $\Psi_{0-1.2}=-0.12 \mathrm{MPa}$ ) can perform as a useful indicator of vine physiological activity and expected water status when irrigation should be triggered as well as kept during berry maturation.

\section{Conclusion}

The results of the present work verify the relationship between soil water potential and plant water status measures. Growers could adjust the plant responses to different soil water content to avoid excess of water deficit situations. With this adjustment, irrigation can be efficiently and easily managed. The rapid response of Watermark ${ }^{\circledR}$ sensors indicated that these sensors are a good tool for monitoring irrigation, as long as soil water is within their range of measurement, that is, between $-0.0 \mathrm{l}$ and $-0.2 \mathrm{MPa}$. They cannot be used in conditions of severe water stress because $\Psi_{0-1.2}$ values close to $-0.2 \mathrm{MPa}$ corresponded with plant responses $\left(\Psi_{\mathrm{em}}\right.$, $\Psi_{\mathrm{md}}$, and $g_{\mathrm{s}}$ ) indicative of severe water stress. Also, it is necessary to make soil water potential adjustments on each crop and local conditions. Leaf water potentials, $\Psi_{\mathrm{em}}$ and $\Psi_{\text {md }}$, and $g_{S}$ differentiated reasonably well plant water status between irrigated and non-irrigated plants. Linking the results of this study with the previous work of our group under similar experimental conditions (Cuevas et al., 2006), we propose using an integrated soil water potential value of $-0.12 \mathrm{MPa}$ as threshold to trigger irrigation and to keep soil water status within an optimal range for grapevine activity during berry growth, avoiding the reaching of an integrated soil water potential of $-0.14 \mathrm{MPa}$.

\section{Literature cited}

Allen, R.G., L.S. Pereira, D. Raes, and M. Smith. 1998. Crop evapotranspiration: Guidelines for computing crop water requirements. FAO Irr. Drainage Papers $56: 15-27$

Araujo, F.J., L.E. Williams, and M.A. Matthews. 1995. A comparative study of young 'Thompson Seedless' grapevines (Vitis vinifera L.) under drip and furrow irrigation. II. Growth, water use efficiency and nitrogen partitioning. Scientia Hort. 60:251-265.

Baeza, P., P. Sánchez-de-Miguel, A. Centeno, P. Junquera, R. Linares, and J.R. Lissarrague. 2007. Water relations between leaf water potential, photosynthesis and agronomic vine response as a tool for establishing thresholds in irrigation scheduling. Scientia Hort. 114:151-158.

Carbonneau, A. 1976. Principes et méthodes de mesure de la surface foliaire. Essai de caractérisation des types de feuilles 
dans le genre Vitis. Annales de l'Amélioration des Plantes 26:327-343.

Charlesworth, P. 2000. Irrigation insights no. 1: Soil water monitoring. Land and Water Australia, Canberra, Australia.

Cifré, J., J. Bota, J.M. Escalona, H. Medrano, and J. Flexas. 2005. Physiological tools for irrigation scheduling in grapevine (Vitis vinifera L.): An open gate to improve water-use efficiency? Agr. Ecosystems Environ. Photosyn. Abiotic Stresses 106:159-170.

Coombe, B.G. 1995. Growth stages of the grapevine. Aust. J. Grape Wine Res. 1:100-110.

Cuevas, E., P. Baeza, and J.R. Lissarrague. 2006. Variation in stomatal behaviour and gas exchange between mid-morning and mid-afternoon of north-south oriented grapevines (Vitis vinifera L. cv. 'Tempranillo') at different levels of soil water availability. Scientia Hort. 108:173-180.

Davenport, J.R., R.G. Stevens, and K.M. Whitley. 2008. Spatial and temporal distribution of soil moisture in drip-irrigated vineyards. HortScience 43:229-235.

Deloire, A., A. Carbonneau, H. Ojeda, and Z. Wang. 2004. La vigne et l'eau. J. Intl. Sci. Vigne Vin 38:1-13.

Dry, P.R. and B.R. Loveys. 1999. Grapevine shoot growth and stomatal conductance are conduced when part of the root system is dried. Vitis 38:151-156.

Dry, P.R., B.R. Loveys, M.G. McCarthy, and M. Stoll. 2001. Gestion des stratégies d'irrigation dans les vignobles australiens. Progrès Agricole et Viticole 118:457-470.

Düring, H. 1976. Studies on the environmentally controlled stomatal transpiration in grapevines. 1. Effects of light intensity and air humidity. Vitis 15:82-87.

Escalona, J.M., J. Flexas, J. Bota, and H. Medrano. 2003. Distribution of leaf photosynthesis and transpiration within grapevine canopies under different drought conditions. Vitis 42:57-64.

Flexas, J., J. Bota, J.M. Escalona, B. Sampol, and H. Medrano. 2002. Effects of drought on photosynthesis in grapevines under field conditions and evaluation of stomatal and mesophyll limitations. Funct. Plant Biol. 29:461-471.

Girona, J., M. Mata, J. del Campo, A. Arbonés, E. Bartra, and J. Marsal. 2006. The use of midday leaf water potential for scheduling deficit irrigation in vineyards. Irrig. Sci. 24:115-127.

Grimes, D.W. and L.E. Williams. 1990. Irrigation effects on plant water relations and productivity of 'Thompson Seedless' grapevines. Crop Sci. 30:255-260.
Hanson, R.B., S. Orloff, and D. Peters. 2000. Monitoring soil moisture helps refine irrigation management. Calif. Agr. 54:38-42.

Hardie, J.W. and S. Martin. 2000. Shoot growth on de-fruited grapevines: A physiological indicator for irrigation scheduling. Aust. J. Grape Wine Res. 6:52-58.

Iacono, F. and J.K. Sommer. 1996. Photoinhibition of photosynthesis and photorespiration in Vitis vinifera under field conditions: Effects of light climate and leaf position. Aust. J. Grape Wine Res. 2:10-20.

Intrigliolo, D.S. and J.R. Castel. 2006. Vine and soil-based measures of water status in a 'Tempranillo' vineyard. Vitis 45:157-163.

Lakso, A.N. 1985. The effects of water stress on physiological processes in fruit crop. Acta Hort. 171:275-286.

Matthews, M., M. Anderson, and H. Schultz. 1987. Phenologic and growth responses to early and late season water deficits in 'Cabernet franc'. Vitis 26:147-160.

Medrano, H., J.M. Escalona, J. Cifré, J. Bota, and J. Flexas. 2003. A ten-year on the physiology of two Spanish grapevine cultivars under field conditions: Effects of water availability from leaf photosynthesis to grape yield and quality. Funct. Plant Biol. 30:607-619.

Myburgh, P.A. 2003. Responses of Vitis vinifera L. cv. 'Sultanina' to water deficits during various pre- and post-harvest phases under semi-arid conditions. South African J. Enol. Viticult. 24:25-33.

Nadler, A. and B. Heuer. 1997. Soil moisture levels and their relation to water potentials of cotton leaves. Aust. J. Agr. Res. 48:923-932.

Naor, A., B. Bravdo, and J. Gelobter. 1994. Gas exchange and water relations in field-grown 'Sauvignon blanc' grapevines. Amer. J. Enol. Viticult. 45:423-428.

Paranychianakis, N.V., S. Aggelides, and A.N. Angelakis. 2004. Influence of rootstock, irrigation level and recycled water on growth and yield of 'Sultanina' grapevines. Agr. Water Mgt. 69:13-27.

Prior, L.D. and A.M. Grieve. 1986. Water use and irrigation requirements of grapevine. Proc. 6th Austral. Wine Ind. Tech. Conf., Adelaide, South Australia, 14-17 July 1986. p. 165-168.

Schultz, H.R. 2003. Differences in hydraulic architecture account for nearisohydric and anisohydric behaviour of two field-grown Vitis vinifera L. cultivars during drought. Plant Cell Environ. 26:1393-1405.
Stevens, R.M. and G. Harvey. 1996. Soil water depletion rates under large grapevines. Aust. J. Grape Wine Res. 2:155-162.

Stevens, R.M. and T. Douglas. 1994. Distribution of grapevine roots and salt under drip and full-ground cover microjet irrigation systems. Irr. Sci. 15:147-152.

Thompson, R.B., M. Gallardo, L.C. Valdez, and M.D. Fernández. 2007. Using plant water status to define threshold values for irrigation management of vegetable crops using soil moisture sensors. Agr. Water Mgt. 88:147-158.

Toome, P. 2002. Soil moisture monitoring with gypsum blocks. Aust. N. Z. Grapegrower Winemaker 82-84:19-23.

Tregoat, O., C. Van Leeuwen, X. Choné, and J.P. Gaudillère. 2002. Étude du régime hydrique et de la nutrition azotée de la vigne par des indicateurs physiologiques. J. Intl. Sci. Vigne Vin 36:133-142.

Turner, N.C. 1988. Measurement of plant water status by the pressure chamber technique. Irr. Sci. 9:289-308.

van Leeuwen, C., O. Trégoat, X. Choné, and J.P. Gaudillère. 2001. The use of physiological indicators to assess vine water uptake and to manage vineyard irrigation. Aust. Grapegrower Winemaker 449:18-24.

Williams, L.E. 2002. L'irrigation des vignes en Californie. Le Progrès Agricole Viticole 119:37-46.

Williams, L.E. and F.J. Araujo. 2002. Correlations among predawn leaf, midday leaf, and midday stem water potential and their correlations with other measures of soil and plant water status in Vitis vinifera. J. Amer. Soc. Hort. Sci. 127:448-454.

Williams, L.E. and T.J. Trout. 2005. Relationships among vine- and soil-based measures of water status in a 'Thompson Seedless' vineyard in response to highfrequency drip irrigation. Amer. J. Enol. Viticult. 56:357-366.

Williams, L.E., N.K. Dokoozlian, and R. Wample. 1994. Grape, p. 85-133. In: B. Schaffer and P.C. Anderson (eds.). Handbook of environmental physiology of fruit crops. CRC Press, Boca Raton, FL.

Yuste, J., J.A. Rubio, and H.J. Peláez. 1999. Predawn leaf water potential and soil water content in vertical trellis under irrigated and non-irrigated conditions in 'Tempranillo' grapevines. Acta Hort. 493:309-321.

Yuste, J., J.A. Rubio, and M.A. Pérez. 2004. Influence of plant density and water regime on soil water use, water relations and productivity of trellis-trained 'Tempranillo' grapevines. Acta Hort. 646:187192. 